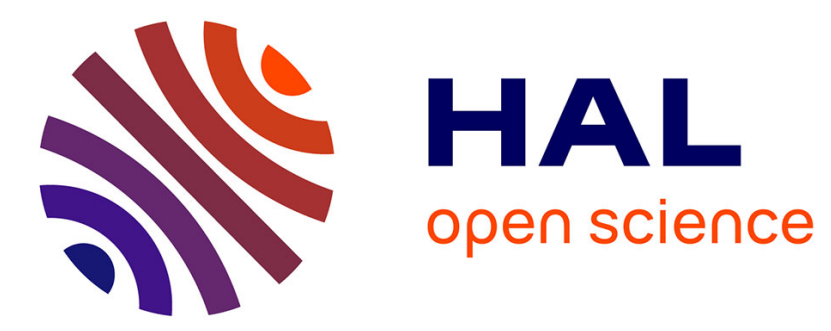

\title{
Weapons Procurement: Domestic Production versus Imports
}

\author{
Ron Smith, Jacques Fontanel
}

\section{To cite this version:}

Ron Smith, Jacques Fontanel. Weapons Procurement: Domestic Production versus Imports. Bellany \& Huxley. New Conventional Weapons and Western Defence, Frank Cass,, 1987. hal-02961554

\section{HAL Id: hal-02961554 https://hal.univ-grenoble-alpes.fr/hal-02961554}

Submitted on 8 Oct 2020

HAL is a multi-disciplinary open access archive for the deposit and dissemination of scientific research documents, whether they are published or not. The documents may come from teaching and research institutions in France or abroad, or from public or private research centers.
L'archive ouverte pluridisciplinaire $\mathbf{H A L}$, est destinée au dépôt et à la diffusion de documents scientifiques de niveau recherche, publiés ou non, émanant des établissements d'enseignement et de recherche français ou étrangers, des laboratoires publics ou privés. 


\title{
Weapons Procurement: Domestic Production versus Imports
}

\author{
Ron Smith, Jacques Fontanel \\ New Conventional Weapons and Western Defence (Bellany \& \\ Huxley Eds.) \\ Frank Cass, London \\ 1987
}

There is a wide range of acquisition modes, from the purchase of an entirely national weapon to importing it from a friendly country, but sometimes from a state wishing to increase its returns to scale. There are some ambiguities in choosing between import and export, when the products are available in the country at widely divergent prices. The quality of technology, industrial property, weapon components and the independence criteria adopted by the state must be taken into account. There are arguments in favor of national public procurement on military aspects, but national security must be able to have the best military technology at its disposal as part of a policy of deterrence. On the industrial aspects, arms production makes it possible to develop research and development, but it is also a financial risk in the framework of an arms race.

Il existe un large éventail de modes d'acquisition allant de l'achat d'une arme entièrement nationale à l'importation en provenance plutôt d'un pays ami, mais parfois d'un Etat souhaitant augmenter ses rendements d'échelle. Il y a quelques ambiguïtés à choisir entre importation et exportation, lorsque les produits sont disponibles dans le pays, à prix fortement divergents. Il faut tenir compte de la qualité de la technologie, de la propriété industrielle, des composants des armes et des critères d'indépendance retenus par l'Etat. Il y a des arguments en faveur des marchés publics nationaux sur les aspects militaires, mais la sécurité nationale doit pouvoir disposer des meilleurs technologies militaires dans le cadre d'une politique de dissuasion. Sur les aspects industriels, la production d'armement permet de développer la recherchedéveloppement, mais c'est aussi un risque financier dans le cadre d'une course aux armements.

Weapon procurement, armament industry, arms import, arms export Achat d'armes, industrie d'armement, importations d'armes, exportations d'armes 


\section{INTRODUCTION}

The contrast in Britain between the import share for defence equipment and for other traded manufactured goods is very striking. Overall 31 per cent of domestic demand for manufactures was met from imports in 1983, up from only 16 per cent in 1970,' and in some sectors of the British market, indigenous production has ceased entirely, leaving UK demand to be met completely by imports. In defence only 5 per cent of equipment expenditure goes to imports; 15 per cent goes to the British share of collaborative projects; and 80 per cent goes to national contracts placed with domestic industry. ${ }^{2}$ These shares might be expected to change in the future as the Tornado programme runs down and the projected Trident programme comes on stream; however, the Ministry of Defence (MOD) does not expect the proportion of the equipment budget which is spent in the UK 10 change dramatically. ${ }^{3}$

The low import propensity for weapons could be explained by the hypothesis that the British arms industry is much more competitive than other sections of British manufacturing. This hypothesis is examined further below. A more likely explanation is that the industry is protected from foreign competition by the buy-British bias of its major customer, the MOD. A comparable position existed in telecommunications equipment before the privatisation of British Telecom. Since privatisation, BT has abandoned the previous policy of maintaining a protected cartel of domestic equipment suppliers and developed new forms of supply. There are a number of interesting similarities between the" defence equipment and telecommunications equipment markets, and many of the same companies are involved.

In general, the present UK government, and most economists, tend to regard sustained protection as a bad thing because of the inefficiency, 
distortions of production, welfare loss and lack of competition it can produce. In contrast, free trade is seen as encouraging the international division of labour and the location of production according to com. parative advantage. Free trade is not always best; but the present government, and most economists, tend to assume that there is a prima facie case against protection unless compelling arguments can be presented to justify it. The main part of this paper, section 3, examines arguments advanced to justify the protection of the defence industries. In defence procurement, choices are rarely simple, and section 2 pro. vides some background to the issues involved in the choice of domestic or imported weapons by reviewing the alternative modes of procurement and their relative costs. Section 4 examines how the observed choices should be interpreted.

It should be emphasised that this paper is concerned to contrast the present policy of protection with an alternative policy of choosing the most cost-effective system irrespective of where it is produced. The alterntive policy being considered is not complete reliance on imports. At a guess, the removal of the present protection might result in an import share of around 25 per cent, rather than 5 per cent, with the effect falling primarily on large projects. The effects of this on the industry would depend on how the companies adjusted, and on the results of exposure to the fresh breeze of competition.

\section{BACKGROUND}

There is a spectrum of procurement modes ranging from purchasing a completely domestic product to an off-the-shelf import, with fine gradations in between. There are no sharp boundaries because much domestic production embodies imported components, while imported weapons will typically involve some UK production or at least require some conversion and adjustment to meet British operational requirements. There is also an ambiguity about what distinguishes an import; whether the crucial characteristic is that it is made in Britain, made by a British-owned firm, or made with British technology. These three aspects need not overlap. Speaking purely hypothetically, British Aerospace (BAc) cquld supply the RAF with a Swiss-developed aircraft, the production of which was sub-contracted to Brazil; while IBM could supply electronic equipment for which both the research and production were done in the UK. In several sectors of manufacturing, the products of Joreign-owned companies are more British than the products of British-owned companies. Other government departments, such as the Departments of Trade and Industry, and Health and Social Security, which sponsor industries, encourage foreign-owned companies to set 
are overhead costs involved in maintaining teans and facilities in the periods between projects. Finally, development costs are notoriously difficult to control, even in a commercial environment. This becomes even more difficult if there is an external contractor undertaking the development work who is being paid on a cost-plus basis (around twothirds of the MOD R\&D budget is spent with industry). Additional difficulties are created if the specifications are subject to change during the process.

\section{Production}

A major influence on the unit cost of weapons is the scale of production. and if a weapon is imported the buyer may gain part of llue advantage accruing from the seller's longer production run. The number of units produced influences costs through pure economies of scale, learning curves and process choice. Where long production runs are expected, it is economic to invest heavily in cost-reducing equipment and processinnovation, 'but for short production runs there is litle return in doing so. The pricing structure will also influence investment choice. BAe's acquission of a $77.5 \mathrm{~m}$. missile simulator was said to be motivated by the fixed price contract for Alarm."

For aircraft, estimates suggest that doubling the number produced tends to reduce unit costs by about 10 per cent. Unit costs will also be influenced by the pattern of ordering. Disruption of scheduling through speeding up or slowing down in response to budgetary pressures, or the spreading of orders among many contractors, will tend to increase unit costs." Although scale is emphasised as the major influence on costs, productivity differences between countries will also influence relative costs, as will product design and the extent to which development and production are overlapped.

\section{Operation}

Even after the weapon has been delivered, and is in operation, expenditure will be incurred for training, associated infrastructure, spares, and replacements, which can be worth as much again to the supplier as the initial contract. "For imported weapons domestic maintenance and repair capacity will be necessary to ensure security and reliability in operation. The Services must also consider running costs. A weapon which is cheap to design and produce might require twice as many people to operate it and twice as much fuel. Of course operating costs depend on deployment and lorce-posture decisions. For instance, the system that is the cheapest for a country operating a conscript army may not be for one operating voluntet forces, because of the difference in the relative cost of labour. 
The sum of cosis in the three phases is usually reter red to as lite-iycle costs. Comparable data on life-eycle costs for difierent systems are rare. These costs are not incurred all at once but over a long period of tinle. The interval between initial specilication and the withdrawal of the last unit from service can be of the order of 30-40 years. Listimating lifecycle costs over that interval is inevitably hazardous. In addition, the relative costs of importing or collaborating as against domestic provision will difler between ypes of system. Aircrali, missiles, warships and small arms each have different cost profiles in tersus of the size of develup. ment cost relative to unit production cost, the minimum elficient scale in terms of number produced, and the trajectory of lechnological change.

Cost control raises a number of distinct, though retuled issues. First. there is the potential sourcing - what range of compinites are allowed to tender and on what terms. Second, there is the meshod of pricing. from cost-plus through various incentivised contracts to lixed price, each with their associated forms of risk-sharing. Third, there is the process of monitoring progress and altributing responsibilicy between MOD, printe contractors and sub-contractors. Increased competition has different implications for each of these issues. Designing appropriate forms of contract and tender also plays an important role.

When the equipment is imported a further uncertaisny is added to the costing: fluctuations in the exchange rate. Commercial firms have a variety of methods of hedging longer-term contracts aguinst exchange rate risk. The agreed price could have a sterling as well as a dollar component, or an gil component as in the case of Siudi Arabia with the purchase of ' Tornado and Hawk aircraft. Insurance in the linancial market can be oblained through forward cover or back-to-back loans. These types of arrangement share the risk (of both gain and loss) from exchange rate movements, and they are sornething to be negotiated by the MOD with the Bank of England or the Treasury, who have overall. responsibility for the procedures used for investment appraisal and for trade-finance within the public sector.

\section{Alternative Procurement Modes}

Costs in the different phases are affected differently by the various procurement modes. Domestic purchase is straightforward: all the costs are incurred domestically in domestic currency. The distribution of cosis in collaborative projects varies depending on the exact arrangements. With weapons collaboration, the typical paltern is that development costs are shared between the partners, culting the costs 10 each. Production is done on a national basis, though the re may be some saving if each country specialises in particular components and some loss if compromise designs are more expensive to produce. Collaboration itseli 
adds a cost penaliy arising from co-ordination expenses ard traluspore needs. There are often complicated, politically negotiated, work sharing and compensation arrangements, which can be sensitive to exchange rate variations and other factors. Operations costs on a collaborative project are probably similar to those for domestic production for a similar design, though the design may be less efficient if there are expensive compromises between partners. Design integrity will influence export potential, which then feeds back on costs.

Experience with collaboration seems to indicate that cost savings are much smaller than the theoretical maximum which would be suggested by splitting development costs and increasing production runs. Nonetheless there are some savings, and in many cases collaboration is the only way to get a 'piece of the action', since a purely national venture would be impractical. Press reports during the European Fighter Aircraft (EFA) negotiations suggested that collaboration might involve a 10 per cent saving over a purely British venture.

Licensed production usually involves the UK paying a royalty which is typically small relative to development costs, and producing the forêign-designed system in Britain." The size of the royalty will depend on demand and supply conditions, which are discussed below with respect 10 imports. Development costs are thus saved by licensed production, a system of known capability is acquired and there may be some technology transfer; but there is a production cost penalty relative to importing. Official figures cite a saving of 35 per cent on estimated price from the competition for the new RAF. basic trainer. ${ }^{12}$ However, no figures are available on what it would have cost had it been produced in Brazil by Embraer, the firm whose design won the competition, rather than in the UK by Short Brothers.

- Arms import contracts tend to be complicated, involving offset deals, credit terms, counter-trade, and various other elements of a complete package." Thus estimating the true price can be difficult. In the negotiation of the import price the bargaining strengths of buyer and seller will depend on the extent of the comperition. If the supplier is the only source and the equipment is essential to the recipient, the price may be high. If there are many potential sources of similar if not identical equipment and the buyer has scope to substitute, the price will be forced down.

Currently, the arms export market is very competitive. On the supply side, many' governments have subsidised the development of indigenous arms industries for strategic and political reasons. This creates strong pressure to export, even if this is done at a loss to the exporting country, whose government subsidises the sale. Prices thus get forced down towards marginal production cost which is much less than average cost. 


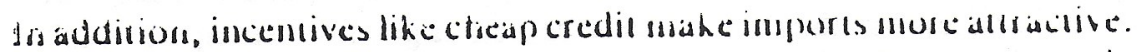
On the demand side, the Third W'orld debt overhastg and llie weith lless in oil prices have caused the markel to contralet. In these circumstances. buyers can force very good deals on many ilems. In the past, exponling arms was seen ads a way of gaining political leverage uver ulher cuuntrics. Now, importing arms from them may be a more ellecilice ualy of gaining leverage.

Press reports on the EFA negotiations suggested that Spain would find it 30 per cellt cheaper to buy from the US than to cullaborate, and this is similar to figures given elsewhere. ${ }^{14}$ A discount of ahout 30 per cent would be consistent with the aircralt selling at around marginal production cost in the export market, the development costs beitug subsidised by the supplier government, and there being some scalc advantages in production. Extra costs would be incurred by the importer because some domestic capacily has to be installed to repair, maintain and ensure the reliable operation of the system. This capacity would already exist with domestic development or licensed production. It is also said that spares, elc. are more expensive from US Ihan from domestic sources, but there are few published figures for this.

The extreme example of the saving from importing is nuckadr delivery systems. Britain acquired the Polaris and is promised the Trident missiles at a fraction of the costs the French incurred for independent development. For Trident a fixed total contribution of $\$ 116 \mathrm{~m}$. al liscal 1982 prices is paid to R\&D costs, with payment spread over ten years, and the UK pays the same production cosis as does the USA. "Whatever is believed about the desirability or operating independence of these weapons, there is no doube that it is cheaper $10 \mathrm{import}$ than 10 develop and build them in the UK. The Chevaline programme illustrated vividly the cost of domestic development of UK nuclear systems.

\section{ARGUMENTS FOR DOMESTIC PROCUREMENT}

The arguments used to justify buying British are familiar. On the military side, it is said that although foreign weapons may be cheaper, British weapons are better, tailored exactly to the needs of UK lorces; and that even were the cheaper foreign weapons procured, the money saved would not go to providing more systems but would be lost from the defence budget. On the industrial side it is argued that a domestic defence industrial base, with its associated design capacity, is essential for strategic independence and that 'infant industry' and 'unfair trade' arguments justify protection. On the economic side it is argued that domestic procurement of weapons creales employmem, boosls lax revenue, helps the balance of payments and produces technological spin-off for civilian production. 
These arguments ale very difficult to evalualc, which is perhapss why they are so popular. There is undoubtedly some truth in all of them in particular cases, but they cannot be accepted as general principles which case the putaive buying British. The issue is whether in each particular of the magnitudes of the eutweigh the costs. Unfortunately, estimates available, and almost nevernents involved in this balance are rarely economic argument used be accepted by the current $\mathrm{Cons}$ (1) this class of protection would not defence. Even in the defence conservative government in any sphere but the other policies, such as sphere, the arguments seem ad hoc, because were these arguments bliever inventories, which would be implied casting doubt on their force. Betow be true, are not implemented; thus aspects of these arguments are the military, industrialiand economic

\section{Milizary Aspects}

The argument that British weapons are better is difficult to disprove because no two weapons systems are exactly comparable, except in imported AEW Nol a choice between a British AEW Nimrod and an in certain important red; the US alternatives, such as AWACS, differ be said to be worh wests. Thus any extra costs, however large, can the nearest alternative. ment of the importance of the have the expertise to make an assessProcurement Executive also differences, in the Services and MOD firms, makin Executive also have close links and loyalties 10 British if a system is cancelled to guarantee an impartial assessment. Even with a little more perseverancer sees service, it can always be said that would have been

Many indirect produced; TSR2 still has its defenders.

always best. Given hents would suggest that British weapons are not development overheads. Brish firmstages that arise from scale and are qualitatively superior by ordirms would need to make products that weapons. There are the fa orders of magnitude to provide better value expensive, late and unable to cases where the British systems proved AEW \& the Torpedo Programmet their performance targets, Nimrod market evaluation suggest that Britis rocent examples. Nor does world money. The French, from a comparabh weapons are beller value for as the UK. In the 1985 US commarable base, sell perhaps twice as many system Ptarmigan cost 70 communications competition the British Foreign sales are the outcom ent more than the French system RITA. does suggesi that foreign buyers are nactors, but export performance and quality mix of British systems. 
Whether or hos Brilish lirms have a comperieve advantage in the international defence nuarket, in sume cases if maj be sensible for the as do procurement schedules: not be available on the internationa markelon, a suilable sysiem maly may be unwilling lo tender for the development and foreign conpanies of the controversial choices between doment contract. However, Inosi are controversial just because there domestic and inporied systems

In three recent jases

the Muliple Launch procureme Launch Rocket System (MLRS), the choice of national higher costs for Hritain the available US alternative, involved not only when needed. a higher priority the cases, it appears that buying Hritish was given Soviel threat.

In 1977 the US offered the AWAC system 10 NATO. The British share of the cosi would have been about $1460 \mathrm{~m}$. in 1985 prices and AWACS would now be operational, compatible with the rest of the NATO system. AWACS would also have generated considerable employmem in the UK through offseis and the possible basing of llic NATO force in the UK. Instead the domestic alternative, the AEW Nimrod, was urdered. on which El bn had been spent by 1986 and the lotal cost is likely to be over $\mathbb{l} 1.5$ bn. The system is still not operating elfectively because of vided for thith the avionics. ${ }^{10}$ Without Nimrod. $A E W$ is being proeventually chose by ancient Shackletons. In late 1986 the government 24 Tigerfish, Sting Ray a A ACS. The Torpedo progranine (Mark has run into repeated aroblems and represents bau talue lor mo 198 prices

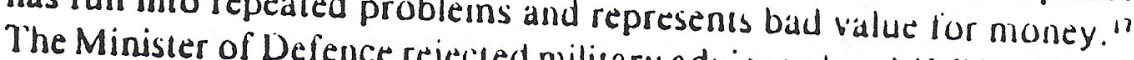

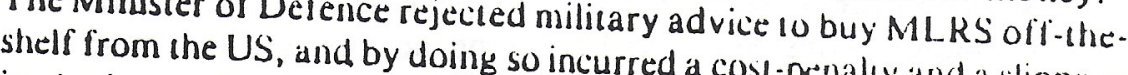
in the in-service date."

Clearly, these are benefius from having equipment exachly tailored willing preferences of British forces, and domestic supplicers rnay be more willing to customise products in this way. But there are also benefits Irom standardised equipmea, compatible and inter-operable with allies. In practice it is difficult to determine whether the claimed advantages of customised equipment will be realised, and decisiuns have to be made on the basis of pronises about what might be delivered in the luture. Even if the advantages are realised, it is not clear whether they will be worth the exira cost and delay, which are also unknown ill advance.

It should also be noted that the argumem for customised weapons contlices with the argument for export potential, since weapons optimised to British requirements are less likely to sell well abroad. To maximise 
the export potential requires designing the equipment in the light of world market needs, as the French are reputed to do.

\section{Industrial Aspects}

There are clearly some areas where a military case can be made for domestic production or conversion capability, irrespective of cost, for strategic reasons. But these cases seem rare and need to be justified individually on the basis of consistent priorities. For the most part, production lead-times are so long that in short conflicts, which is what current UK policy is geared towards, supply depends on inventories, domestic or foreign, rather than production capacity. The government concluded that the Falklands Campaign "demonstrated the value of a broadly based national defence industry, and the benefits of an in-house research capability'." However, the report neither spells out which aspects of capacity were crucial nor mentions, in the discussion of procurement, the decisive role of US supply. particularly of the Sidewinder AIM $9 \mathrm{~L}$ for the Harrier.

If a defence-industrial base is required, then there should be a defence-industrial policy which specifies what is needed, and the best way that it can be acquired. The optimal strategy is likely to involve importing a range of systems. The money saved by doing this can be used to finance more effective ways of maintaining the capability required. The MOD could subsidise some strategic research for future eventualities; acquire essential technologies by licensed production of foreign designs; and maintain adequate inventories of materials likely to be needed in conflict.

There is a more general argument for independence, that does not rest on narrow military considerations, but on the more general economic and political freedom of action that indigenous weapons production, and the like, provides to a nation. This is the French position, but as the Westland and Land Rover disputes demonstrated, many British politicians become embarrassed about being quite so explicit about the need for the UK to resist the yoke of US hegemony. In any case, in both countries the argument is of ten more about symbolism than economics, and centres on prestige items (aircraft or nuclear reactors, space launchers or mainframe computers) rather than the more prosaic products which have proved central to international competitiveness. The countries which have prospered in international trade, like West Germany and Japan, have not diverted their scarce development resources to high profile small market projects of this sort.

It can be argued that the cheapness of imported weapons arises from unfair trade, since other governments subsidise their arms exports and pay the development costs. Thus the argument suggests that to maintain 
Iairness oelween defence contraciors the British guvermucull must also incur heavy costs duplicating the development work of uthers and selling weapons 10 foreigners at below average cost. This simply seems to be a waste of money which can be justified only for the limited areas specified as essential by a defence-industrial policy, or uliere there s. a danger of one supplier oblaining a monopoly. This is not the case for most of the systems under consideration. Rather than a problem of monopoly there is a problem of overcapacity in the arms market. Connplete monopoly is also difficult to maintain, since unce the technology, has been developed it can usually be copied al a cost.

The argunem that one becomes locked in 10 loreign suppliers. becoming completely dependent on them, does not seem compelling because one becomes even nore strongly locked in 10 a domestic supplier. It is much easier to cancel an import order if the weapun does not live up to promises than it is to cancel a domestic or cullaborative order. There is also the danger of becoming locked into old technologies. If the capacity and experience is established in the UK' 10 produce traditional weapons, it establishes a bias against new approaches which might threaten that investmeni.

The 'infant industry' argument is that domestic products are currently high in cost because of lack of scale, and that protection will enable the scale of production needed to compete internationally to be reached. The argument is weak in this sector, because existing protection has failed to provide this scale advantage. The argument is leading every country to protect its arms firms, resulting in a world industry with too many producers almost none of whom can reach ninimum costs because the size of the total market is inadequate to support them all. For instance, it seems unlikely that the European helicopter market and likely export sales will be sufficient to maintain four European producers.

\section{Economic Aspects}

A range of indirect economic effects on taxes, jobs, technology and exports is used to justify procurement of domestic rather than foreign weapons. This type of justification raises two questions. One is empirical: how large are these benefits? One is theoretical: can these benelits justify the costs of protection?

On the empirical question, despite the frequency with, which the contrary is claimed, most published research indicutes that militaty projects are a very ineffective form of economic intervention; " rather, following this policy has damaged Uk economic mel lurmance in the past. If state intervention to achieve such economic objetlives is appropriate then there are more eflicient meihods arailable. Relative to other types of government expenditure military projects create 
comparatively lew jobs per billion spent, because of the skill and development intensity of the process. There is also liule evidence of much commercially successful technological spin-off from the half of the public R\&D budget which is devoted to defence in Britain. Given the size and volatility of the market, the entry of many new competitors. and the poor demand prospects, the likely return from arms exporis is not great. There may be a case for subsidising and protecting some industries because of growth prospects, employment potential and economic linkages they provide. Hut the evidenice suggests that these objectives would be better served by directing the scarce financial and scientific resources at civilian not military industries.

The theoretical question is more difficult because there are such a variely of economic theories. Socialist-Keynesian governments, like that in power in France until March 1986, have an interventionist philosophy and argue that protection, subsidies and government contracts have an essential role in the maintenance and re-structuring of domestic industry. But Conservative-Monetarist governments, like that currently in power in the UK, have an enterprise philosophy and argue that market forces decide such things better than bureaucrats. These bureaucrats should confine themselves to their expertise, choosing the best weapons, and not indulge in economic forecasting. picking commercial winners and interfering with the market. Moreover, this philosophy asserts that markets work efficiently and that any incidental benefits that can be predicted will already be reflected in relative prices. Thus adding in extras for tax revenue and employment would involve double counting. The UK government's stated policy on defence procurement reflects
this philosophy.

It is not Government practice to lake account of tax and national insurance flowbacks in comparing tenders from United Kingdom and overseas contractors because the Government consider that the acceptance of United Kingdom tenders which are internationally uncomperitive does not lead to a sustainable increase in employment in the economy as a whole. It is accepted that there may be short term employment benefits, in particular sectors of the defence industry, but the adverse effects of uncompetitive purchases on the economy ihrough higher public sector borrowing, interest rates, rate of inflation, or the exchange rate, lead to increases in unemployment in other areas which negate the assumed flowback
benefits.

However, the next sentence rapidly retreats from this firm, principled stand. 'Defence procurement decisions are nevertheless taken in the light 


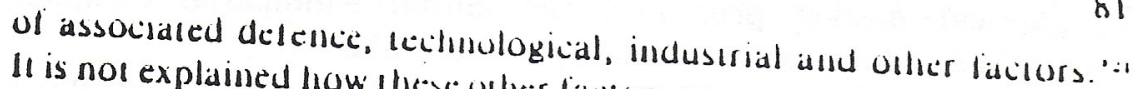

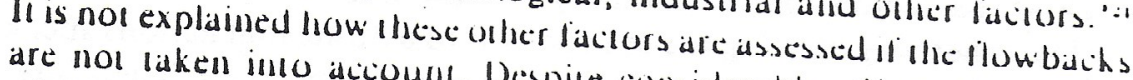
of Commons Detence Com Despite considesable ellorr, He Housc procedure.

The French Socialist government, with ils scepticism about narket solutions, applied its interventionist philosophy' consistendly with its endeavours in o her areas. To the defence industries government, wilh ils enterprise other areas. The Bribish Conservative market solutions to other industries like chy, has endeavoured 10 apply ments have had their successes and lailures and and cars. Both governup to their ideals. However and failures and have nor always lived declaratory policy of the need in UK defence procurement, despite a been made lo apply undite for more competition, licule allempl has coneraciors.

The enserprise - interventionist displ interventionist would argue that dispule has many ramilicidions. The irreplaceable loss of the flags lack of protection would lead to the ence, design teams and technolog of British industry wilh theil experiit has been protection and supportoge The enterprise answ'er would be that resulted in poor British ecomoort of these arthritic giants which has supported shadow has smothered performance, and that liceir stale who could have contributed to growe small firms and venture capitalists the winds of foreign competilion could reviasing the conglomerates to space for new British entrants to llourish.

This theoretical argument is ind manysh.

current UK defence procuremen many respects acidemic because the interventionist philosophy witent policy consists of neilher a colterent nor a consistent enterprise policy, willingled defence-industrial policy; of international market forces. willing to rely on the bericticial effects is not only contradictory butes. The policy which is being implemented costs and budget constraints will force some change.

\section{CONCLUSION}

Econonists rely heavily on a single approach, taught to them by Adam interest. This approach can be used in as the outcome of rational selfthe objective of interest declared by the agents. One way involves laking etc) and the constraints to which they are subject available bud security. instance), and then trying to derive the optimum actions. The optimum defence sphere the large deviations between the optimully latien. In the 
acrions then have to be explained in terms of nonteconomic factors such as political-markel processes, the military-industrial complex, generalised failure to act rationally and the like.

The other way of using the approach is to assume that actions speak louder than words, especially where money is concerned. Therefore, one should regard the observed actions as being optimal for some real objective, which may be different from that declared by the agent involved. Then the analysis involves trying to infer from the observed actions what the real objectives are. Interpreting the choices in this way reveals multiple conflicting objectives each with different weights. Concern with the Soviet threat is one of these ubjectives; but in many decisions, like AEW, it seems to come a long way down the list, subordinate to national prestige and the support of British firms. Thus, it is not surprising that the peace movement should discount government warnings of pressing security danger, when government procurement choices also seem to discount such dangers.

We are graseful for suppori under an ESRC/CNRS financed collaborative siudy of the British and Frenich deferice efforts. Very similar issues to those discussed in this papet are addressed by k'. Hartlcy. NiATO Arms Co-operation: A Sisdy in Economics and Polisics, Allen and Unwin, London, 1983. un which this paper draws heavily. We are also grateful to Keith llariley. Linda Hesselman. Hugh Davies and Huw Dixon for comments.

1. Econonuc Progiess Report. No.178. June-July 1985. HM Treasury.

2. Prof. Sir Runald Mason. 'Delence Research and Developmeni and Wesiern Industrial Policy: Parr ' ' in 'New Technology and Wesiern Securily'. Adelphi Papers 199. IISS. London, 1985. Parl 11, by Henri Matre gives a French perspective. The imporl and collaborative shares in France are of a similar magnilude.

3. Evidence by Sir Clive Whitmore, 'Defence Commitments and Resources', Third Report

- from House of Commons Defence Commitue, Session 1984-85. HC37-1. I1 and 111 (HDCD hereafier).

4. M. Brech and Margarel Sharp, Inword Invesiment. Chatham House Papers No.21. Roulledge Kegan Paul. London, 1984.

5. The D/P racios for Tornado and Harrier GRS come from HCDC II Pp. 143-6 and 157. which gives development costs of $2333 \mathrm{~m}$. and producrion costs of $[853 \mathrm{~m}$. for $60 \mathrm{GRS}$. Tornado figures are production cosis of C6. $5 \mathrm{bn}$. for 385 units and development costs of 2.9 br. The other RRD ligures come from Siasement on Defence Essimases. 1985. Cmnd $94301+11$. HMSO, London, Table 3.1 (hereafier SDE).

6. The average $D / P$ racio of 38 per cent is equivalent 10 an $R \& D$ io sales ratio of 27.5 per cent. If one added company-linanced R\&D to the numerator and exports to the denominator, il might lall 10 just under 29 per cent. Business H'eet $8 / 7 / 1985$, Rdi Scoreboard gives derails of company-sponsored K\&D expenses (i.e. excluding KKD performed under contract 10 others such as the US (jovernnient) as a percentage of sales for the US in 1964. These data are reported to the SEC on form 10-K. Comparable data are not availabie for the UR. For all industries the uverage R\&D to sales ratio is 2.9 pes cent. Of the 32 industries considered only eight spend over 5 per cent of sales on R\&D. the highesi being semiconductors al 8.2 per cent. followed by computers 7.4 per cent. peripherals 7.3 per cent and drugs at 7.1 per cent. Aerospace is 4.8 per cent. 


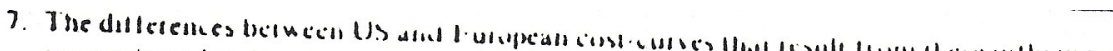

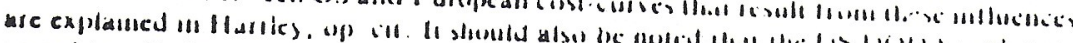

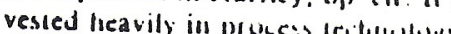

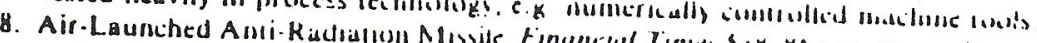
and use of the irissile simulater.

. The governin

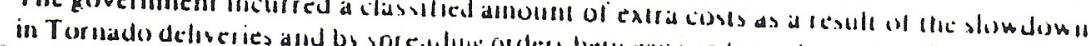

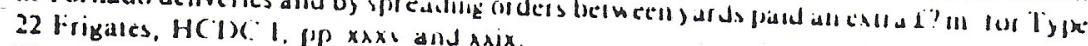

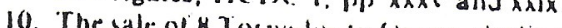

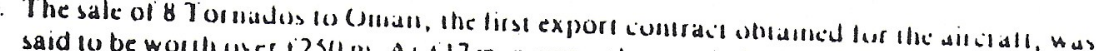

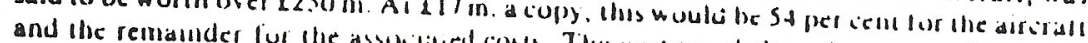

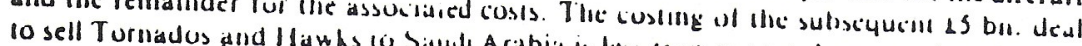

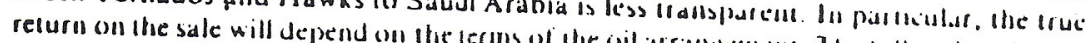

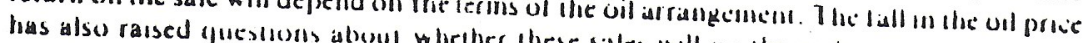

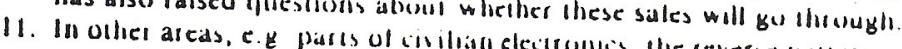

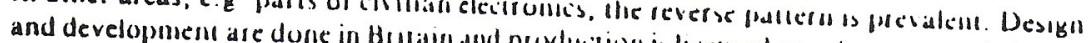

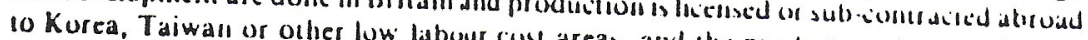
12. SDE, P. 37.

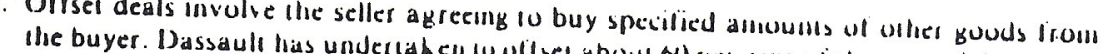
40 Mirage 2000 aircrall

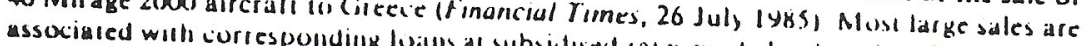
ierms, handled in the Uk by the lic al subsidised lates made by the selles. These credil

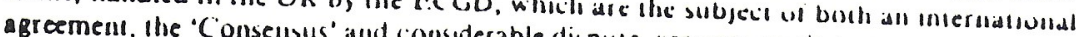
nents. ECCiD cover was iund collsiderable dispule, are very coully lu eapurung governa form of barter wher important on the sale of Tormado lu Cinas. Cuunter-trade is

14. Harlley, op. cil.

15. HCDC, pp. 266, 269, 272

16. The Listener, $21 \mathrm{lcb}$. Iyss.

17. Repors by the Comptroller and Audstor General, HC 2y1, 21 Alarils Iyks.

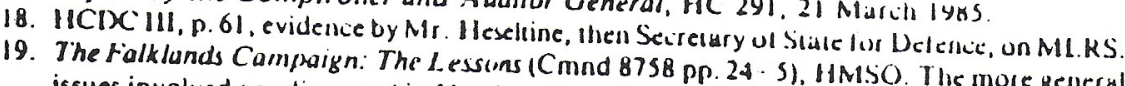
issues involved are discussed in Base', unpublished.

20. There is a large literalure on the economic eflecis of miluary expendilusc and sorne of the references can be found in J. P. Dunne R. P. Smith. The Economic Consequences of Reduced UR Military Expenditure'. Combridge Jowrnal of Ecunumses, Vol. 8. Sept. 1984. pp. 297, 310.

21. HCDC III-17, quoling a writter. answer by the Parliameatars Under-Secretary of Stale for Defence Procurement lo a Parliamentary Question. 


\section{Bibliographie}

Arrow, chenery, Minhas, Solow (1961), Capital labour sustitution and economic efficiency. Review of Economics and Statistics, Vol. 43.

Ball, N., Lietenberg, M. (1983), The structure of the defense industry, Croom Lem, London.

CBO Study (1983), Defense spending and the economy, Washington.

Fontanel, J. (1982) Military Expenditure and Economic Growth: France, Morocco. report written for the United Nations, 6.

Fontanel, J. (1984), L'économie des armes, La Découverte, Paris

Fontanel, J. Smith, R. (1985), Analyse économique des dépenses militaires, Stratégique.

Fontanel, J., Smith.R ; (1985), L'effort économique de défense, Arès, défense et sécurité.

Fontanel, J., Smith, R. Willett, S. (1985), Les industries d'armement de la France et du Royaume-Uni, in L'effort économique de défense (J.Fontanel, , Ron Smih, Ed.) Areès, Défense et Sécurité,

Fontanel, J. , Humm, A. Smith, R. (1985), La substitution capital travail dans les dépenses militaires, Arès Défense et Sécurité, SDESI.

Fontanel, J., Saraiva, J.D. (1986) Industries d'armement et développement, in "Désarmement pour le Développement" (Fontanel \& Guilhaudis, Ed.), ARES, Défense et Sécurité, Lyon, Grenoble, 1986

Hartley, K. (1983), NATO Arms Co-operation. A study in Economics and Politics, Allen and Urwin, London.

Mason, R. (1985), Defence Research and Development and Western Industrial Policyn in New Technology and Western Security, Adelphi Paper 199.

Gansler, J. (1982), The defense industry, MIT Press.

Kaldor, M. (1980), Technical change in the Defence industry, in Technical Innovation and British Economy Performance, MacMillan.

Maddock, I. (1983), The commercial exploitation of defence technology, MEDO.

Percebois, J. (1984), Le financement du nucléaire militaire en France (1959-1969), Colloque de la Fondation de Gaulle, Besançon.

SIRPA (1985), L'armement en France, Dossier d'information n 77 . Mai

Smith, R.P. (1980), The demand for military expenditure, Economic Journal, Vol. 90. December.

Smith, R. (1980), Military expenditure and investment in OECD countries, Journal of comparative Economics, 4.

Smith, R., Humm, Fontanel, J. (1985), The Economics of exporting arms, Journal of Peace Research, 2(3).

Smith, R. P., Humm, A. and Fontanel, J. (1987) Capital-labour substitution in defence provision, in Defence, Security and Development $\mathrm{S}$. Deger and R. West, (Eds.), Frances Pinter, London. 